\title{
Students' Perception of Utilizing Podcasts To Learn English Listening Skill
}

\author{
Hersagita Anissa Hayati \\ Hersagitaah@gmail.com \\ Universitas Singaperbangsa Karawang \\ Maman Suryaman \\ maman.suryaman@fkip.unsika.ac.id \\ Universitas Singaperbangsa Karawang
}

\begin{abstract}
In this day of advanced technology, learning English can be done anywhere, not just through books, but also through the internet. Podcasts can assist in learning listening English during this pandemic since they can be listened to anywhere and at any time, and podcasts are also an enjoyable media. The purpose of this study is to find out what students think about using podcasts to learn English. The research sample was made up of ten people between the ages of 18 until 21, who filled out an online questionnaire. Podcasts are a flexible medium for learning English, according to one study. As a result of this research, it can be concluded that podcasts have become an interesting way to practice English listening skills.
\end{abstract}

Keywords:Utilizing Podcasts, Learn English, Student perception, Listening Ability

\section{INTRODUCTION}

In this modern era English is not a difficult language to learn because sophisticated technology makes it possible for anyone to learn it. Today, digital technology is preferred by many as the first go-to source of a dynamic hub of knowledge and learning (Merzifonluoğlu\&Gonulal, 2018). English has four skill namely listening, speaking, writing, and reading. Humans tend to listen more than they read, speak, or write, which arguably puts listening at the heart of the language learning process (Talip GONULAL, 2020). In E-learning to learn English and other foreign languages for non-native speakers, podcasts are one kind of e-learning that can be used to learn listening skill, pronunciation, vocabulary builder and etc.

Listening skills are a set of abilities that everyone should have when learning English in order to develop other skills. Podcasting, which was first presented in 2005, is a cutting-edge method for transmitting audio files. Podcast is a type of media that uses an internet connection to deliver audio recordings. Listening is defined as the process of identifying and understanding the speech of the 
speakers. It involves understanding the speaker's accent or pronunciation, speaker's grammar and vocabulary, and comprehension of meaning (Saricoban, 1999). These four activities should be possible for the listener to do at the same time. As an input skill, listening plays a vital role in student's language development (Saricoban, 1999). Podcasts are usually in the form of audio or video files, and considered of importance in improving learners' listening skills (Khedidja and Mechraoui 2015).

Podcasts are often in MP3 format and can be listened to on a variety of digital devices, including laptops, tablets, and smartphones. Podcasts are automatically delivered to subscribe users and they can listen to them whenever and wherever they want (Shelly \&Frydenberg, 2010). The usage of podcasts in English learning is linked to autonomous learning. Learners can listen to podcasts from a variety of sources, such as on YouTube, Spotify, Soundcloud, and so on.

Several studies on student perspective in using English podcasts have actually been carried out by many researchers, such as in Iran which discussed the Effect of Using English Podcast on Idiom and Vocabulary Learning of Iranian EFL Learners. Learners have a significant positive attitude toward learning via podcasts. This study was conducted to determine Indonesian listener opinions about the influence and impact of learning English through podcasts. This study is significant because it will determine whether or not podcasts can aid in the learning of English.

\section{LITERATURE REVIEW}

Learning English in this fast-paced technological era is done not just through books, but also through social media on a variety of platforms, one of which is learning English through podcasts. Podcasting has become popular in a variety of educational settings in recent years. In subject courses, podcasting is often used to deliver recorded lectures and speeches (O’Bryan \&Hegelheimer, 2007), enrich distance learning, facilitate self-paced learning, aid slower learners, and to further develop advanced and/or highly motivated learners, among other uses (Walls et al., 2010). According to Jordan (2007) as cited in Bustari, Samad\& Ahmad (2017, p. 97) "the term podcast is a combination between the words pod (i.e., from the brand name iPod) and broadcast." In accordance with the definition above, podcasts can be classified as one of the media that can be used in the teaching and learning process, particularly in the teaching of English.

\section{Learning English ThroughTechnology}

Technology has always played a significant role in the teaching and learning process. According to PourhoseinGilakjani (2013), the use of technologies has the great potential to change the existing language teaching methods. PourhoseinGilakjani and Sabouri (2014) emphasized that by using technology, learners can control their own learning process and have access to many information over which their teachers cannot control. As in the case of using podcasts to learn English, where podcast listeners can pick their favorite podcast channel, chategories, and episode. 
The use of Podcasts in Learning Listening English

Listening is undoubtedly best improved by simply listening. Increased exposure to a large amount of comprehensible aural input is called extensive listening (EL) (Talip GONULAL, 2020). According to Vandergrift and Goh (2012), there are three important principles for effective EL practice: variety, frequency, and repetition. L2 learners should listen to a variety of listening materials on a various topics and themes to familiarize themselves with the structures of various listening texts. A variety of technologies have been developed, and one of them that provides material for language learning is the podcast. Based on Marisa and Zaiyana (2018) One of the skills in English that is considered difficult to be learnt for EFL learners in Indonesia is listening since it needs listeners' focus and concentration. Ahmed (2016) in her study found that implementing podcasts in language teaching can assist learners to have a good understanding about the content and to develop their ability in listening comprehension. Ramli\&Kurniawan, (2017) emphasized that Listening is considered profound in the developmnet of speaking since it provides input that can promote speaking. In other study as pointed out by Iskanda, Ahmad, and Diana (2017) they said podcast media affirmatively shows good point for students in case of it would bring the students closer to the target language, and it affects students' attitude and motivation. Podcasts have the potential to help language acquisition and can be used as a supplement to traditional methods. Wei and Ram (2016) did a qualitative study and found that podcasts have the ability to boost students' proficiency and awareness during the language learning process. Furthermore, podcasts allow students and curriculum developers to widen the learning style options in a more userfriendly manner.

\section{METHOD}

This research is a qualitative research conducted in June 2021. The dependent variable is learning English listening skills, while the independent variable is student perceptions of utilizing podcasts. Students between the ages of 18 and 21 are used as research participants in this study. There are a total of ten people who have responded. As a result, a questionnaire survey was employed to collect data to determine how students' thoughts on utilizing podcasts to learn English were used. Students who used podcasts to learn English were included in this study. The information was gathered through Twitter-based questionnaires circulated on social media.

\section{Instrument}

The perception of students' learning in learning English through the usage of podcasts is the dependent variable in this study. A questionnaire instrument was used to assess students' perceptions. A questionnaire is a type of research instrument that consists of questions and is used to gather information from respondents.

\section{Data Collection}

Data was gathered from a Twitter survey of respondents who used social media or the internet. The information was gathered using 7 different measures items from questionnaires that were used to 
determine how students felt about learning English using podcasts. Two open questions were included in the questionnaire to invite students to provide their thoughts on the major benefits and drawbacks of using podcasts for instructional reasons.

\section{RESULT AND DISCUSSION Result of Questionnaire}

The survey was completed by ten people who identified themselves as students. According to the results of the survey, students' podcast listening habits differed greatly. The majority people subscribed to between $2-5$ podcasts $(50 \%)$, listened to podcasts 1 - 2 times a week (30\%)

According to the results of the survey (Table 1), podcasts can help students improve their listening abilities, with $60 \%$ of students strongly agreeing that listening to podcasts can help them expand their vocabulary. Approximately half of the students (strongly agree and agree) believe that listening to a podcast can motivate them to learn English. However, it appears that some students find it difficult to identify podcasts that are relevant to their interests (30\%).

Table 1

Podcast usage rating

\begin{tabular}{|c|c|c|c|c|c|}
\hline \multirow{2}{*}{ No } & \multirow{2}{*}{ Question } & \multicolumn{4}{|c|}{ Respons } \\
\hline & & Strongly Agree & Agree & Not sure & Disagree \\
\hline 1. & Listening to podcasts improves my English listening skills. & $70 \%$ & $30 \%$ & $0 \%$ & $0 \%$ \\
\hline 2. & Listening to podcasts improves my English vocabulary & $60 \%$ & $40 \%$ & $0 \%$ & $0 \%$ \\
\hline 3. & $\begin{array}{l}\text { Listening to podcasts increases my motivation to learn } \\
\text { English. }\end{array}$ & $50 \%$ & $50 \%$ & $0 \%$ & $0 \%$ \\
\hline 4. & It's easy for me to find podcasts that match my interests. & $40 \%$ & $30 \%$ & $30 \%$ & $0 \%$ \\
\hline 5. & Listening to podcasts is an enjoyable experience. & $70 \%$ & $30 \%$ & $0 \%$ & $0 \%$ \\
\hline
\end{tabular}

The second section of the survey (Table 2\&3) asked students about their thoughts on the benefits (Table 2) and problems (Table 3) of utilizing podcasts. Podcasts, according to the majority of them, can help with listening skills and are more flexible because they can be accessed anywhere and at any time. Podcasts can help improve listening focus and sensitivity, which is associated to learning new vocabulary, according to the authors. Putman $\&$ Kingsley (2011) emphasized that Students have the opportunity to add vocabulary to listening material, not only that, but listening sensitivity can be used to correctly train vocabulary. 
Table 2

\section{Summary of Comments Regarding the Advantage}

\begin{tabular}{|l|l|}
\hline \multicolumn{1}{|c|}{ Advantage } & \multicolumn{1}{c|}{ Example Comments } \\
\hline Language Learning & Can practice listening skills \\
\hline Usage & Flexible can be access at any time \\
\hline
\end{tabular}

The students also named problems (Table 3) they had encountered in listening to podcast, they largely indicated the difficulty was with the accent, and not according to the rules of grammar, and that if there was unfamiliar words, it would make it difficult to comprehend. Furthermore, native speakers' speaking pace is a common issue, especially for those with a British accent, the most severe difficulty in understanding listening, as well as slang terms that are occasionally unknown.

Table 3

Summary of Comments Regarding the Problems

\begin{tabular}{|l|l|}
\hline \multicolumn{1}{|c|}{ Problems } & \multicolumn{1}{c|}{ Example Comments } \\
\hline Accent & $\begin{array}{l}\text { British accent sometimes it's } \\
\text { hard for me to catch the meaning }\end{array}$ \\
\hline Unfamiliar words & Many unfamiliar words \\
\hline Language & Native speaker speech rate \\
\hline
\end{tabular}

The results show that the podcast has an impact on pupils' listening abilities. The results of the poll show that listening to podcasts has a positive impact. Because it is a pleasant medium to use, the students agreed that the podcast enhanced their motivation to study English. Podcasts, according to Dervin
(2006), can aid to reinforce independent learning and motivation.

\section{CONCLUSION}

Students have responded positively to the findings of this study in terms of enhancing their listening skills. They specifically agree that podcasts are a good technique for learn listening. It's simple to use, flexible, engaging, and enjoyable. Furthermore, this media can be used at any time and in anywhere and podcast increase their motivation in studying English.

\section{REFERENCES}

Abdul Samad, I., Bustari, A., \& Ahmad, D. (2017). THE USE OF PODCASTS IN IMPROVING STUDENTS' SPEAKING SKILL, 3. Retrieved 19 June 2021, from.

Abdulrahman, T., Basalama, N., \& Widodo, M. (2018). THE IMPACT OF PODCASTS ON EFL STUDENTS' LISTENING COMPREHENSION. International Journal Of Language Education, 2(2), 23.https://doi. org/10.26858/ijole.v2i2.5878

Ahmadi, D. (2018). The Use of Technology in English Language Learning: A Literature Review. International Journal Of Research In English Education, 3(2), 115-125. https://doi. org/10.29252/ijree.3.2.115

Alshaikhi, D., \&Madini, A. (2021). Attitude toward Enhancing Extensive Listening through Podcasts Supplementary Pack. Retrieved 19 June 2021, from.

Asyifah, D., \&Indrian, L. (2021). Students Perspective: The Impact Of Podcasts On EFL Students Listening Comprehension, 4(2). https://doi.org/DOI: https:// doi.org/10.31605/eduvelop.v4i2.858

GÖNÜLAL, T. (2020). Improving Listening Skills with Extensive Listening Using Podcasts and Vodcasts. International Journal Of Contemporary 
Educational Research. https://doi.org/10.33200/ ijcer.685196

Indahsari, D. (2020). Using podcast for EFL students in language learning. JEES (Journal Of English Educators Society), 5(2), 103-108. https://doi. org/10.21070/jees.v5i2.767

Jordan, M. (2007). What a podcast is and everything you need to know about podcasting. Technology in Education. Retrieved January 13, 2017 from http:// www.americanchronicle.com/articl es/viewArticle. asp?articleID $=47099$

Kaouter.Mechraoui , Amal., K., \&Rafeeq, M. (2015). The Effect Of Listening To Podcasts On Incidental Vocabulary Acquisition, 3(1). Retrieved 19 June 2021, from.

Merzifonuoğlu, A., \&Gonulal, T. (2018). Book review: M Carrier, RM Damerow and KM Bailey (Eds). Digital language learning and teaching: Research, theory, and practice. Language Learning \& Technology, 22(1), 65-68.

O'BRIEN, A., \& HEGELHEIMER, V. (2007). Integrating CALL into the classroom: The role of podcasting in an ESL listening strategies course. ReCALL, 19(2), 162-180. doi:10.1017/ S0958344007000523

PourhoseinGilakjani, A. (2013). Factors Contributing to Teachers' Use of Computer Technology in the Classroom. Universal Journal Of Educational Research, 1(3), 262-267. https://doi.org/10.13189/ ujer.2013.010317

Ramli, A., \&Kurniawan, E. (2018). The Use of Podcast to Improve Students' Listening and Speaking Skills for EFL Learners. Proceedings OfThe International Conference On English Language Teaching
(ICONELT 2017). https://doi.org/10.2991/ iconelt-17.2018.42

Saricoban, A. 1999. "The Teaching of Listening" The Internet TESL Journal Vol. V No. 12 December 1999. Available at http://iteslj.org/Articles/ Saricoban-Listening.html.

Shelly, G. B., \&Frydenberg, M. (2010). Web 2.0: concepts and applications. Boston: Cengage Learning.

Sugiyono. (2010). MetodePenelitianKuantitatif, Kualitatif, dan R\&D. Bandung: Alfabeta.

Tabatabaee, G., \&Rezvani, E. (2019). EFFECTS OF USING ENGLISH PODCASTS ON IDIOMS AND VOCABULARY LEARNING OF IRANIAN EFL LEARNERS. Indonesian Journal Of Learning And Instruction, 2(01). https://doi.org/10.25134/ ijli.v2i01.1680

Vandergrift, L., \& Goh, C. C. (2012). Teaching and learning second language listening: Metacognition in action. New York: Routledge.

Walls, S., Kucsera, J., Walker, J., Acee, T., McVaugh, N., \& Robinson, D. (2010). Podcasting in education: Are students as ready and eager as we think they are?. Computers \& Education, 54(2), 371-378. https://doi.org/10.1016/j.compedu.2009.08.018

Yeh, C. (2014). An Investigation of a Podcast Learning Project for Extensive Listening. Language Education In Asia, 4(2), 135-149. https://doi.org/10.5746/ leia/13/v4/i2/a04/yeh

Yoestara, M., \&Putri, Z. (2019). PODCAST: An alternative way to improve EFL students' listening and speaking performance. Englisia Journal, 6(1), 15. https://doi.org/10.22373/ej.v6i1.3805 